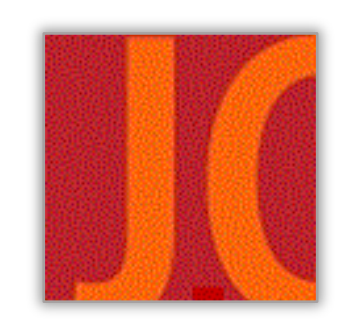

\title{
Walking Pedagogy for Science Education and More-Than-Human Connection
}

\author{
Lee Beavington \\ Kwantlen Polytechnic University \& Simon Fraser University
}

\begin{abstract}
:
This literary-visual métissage weaves together stories, scholarship and photographs. What can be unearthed-science education, embodied knowledge, environmental ethics-when we walk on the land? Embodied and sensorial engagement fosters relational and enlivening educational experiences. Whether preschool or post-doc, direct sense experience offers not only active and experiential pedagogy, but also a spiritual attunement with the natural world. Now, amid the climate crisis and screen fatigue pandemic, such Earth resonance is of utmost import. Let us walk through a snowy forest, ponder what counsel our shoeless feet (and David Abram) afford us, and envision the learning environment as an emergent and adaptable opportunity for connection and wonder.
\end{abstract}

Keywords: science education; embodied learning; place-based learning; David Abram; literary métissage 


\section{La Pédagogie de la marche pour l'enseignement des sciences et la connexion plus qu'humaine}

\section{Résumé :}

Ce métissage littéraire-visuel mêle des histoires, l'érudition et des photos. Que peut-on découvrir-l'enseignement scientifique, des connaissances incarnées, l'éthique environnementale-lorsque nous marchons sur la terre? L'engagement incarné et sensoriel favorise les expériences éducatives relationnelles et animantes. Qu'elle soit préscolaire ou postdoctorale, l'expérience sensorielle directe offre non seulement une pédagogie active et expérientielle, mais aussi une harmonisation spirituelle avec le monde naturel. Aujourd'hui, au milieu de la crise climatique et de la pandémie de fatigue écran, une telle résonance de la Terre est de la plus haute importance. Marchons à travers une forêt enneigée, réfléchissons aux conseils que nos pieds sans chaussures (et David Abram) nous offrent, et envisageons l'environnement d'apprentissage comme une opportunité émergente et adaptable de connexion et d'émerveillement.

Mots clés : l'éducation scientifique; l'apprentissage incarné; l'apprentissage basé sur le lieu; David Abram; le métissage littéraire 
My feet crunch through snow. Thirty-five university students trail behind, silent except for their slow, icy footsteps. Red alders loom to either side, leafless limbs like veins reaching for air. This unexpected moment will be one of the most profound in my nineteen years of teaching, a moment that almost never happened.

\section{Of Snow and Hobbits—and Walking as Time Gained}

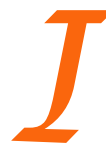
am an interdisciplinary artist, a scientist and a place-based educator. In addition to teaching in the Faculty of Education at Simon Fraser University, I have also taught and worked in five faculties at Kwantlen Polytechnic University (KPU). This includes work in teaching biology, in the expressive arts, at the Amazon Field School, and as a learning strategist. I regularly lead ecology walks, and I have also been contracted to teach K-12 students in inquiry-based, exploratory, responsive learning. Drawing on these experiences, my aim in this paper is to offer a literaryphotographic métissage (Hasebe-Ludt et al., 2009; Hasebe-Ludt \& Leggo, 2018) in three parts. The first section takes us on a forest walk through snow and outlines three reasons why embodied and sensorial engagement foster relational and enlivening educational experiences. The second section finds us barefoot in fern alley. We ponder what we can notice with our shoeless feet (including an activity facilitated by David Abram) and how this fits into curriculum. The third section outlines the Ecology in $1 \mathrm{~m}^{2}$ study, which facilitates remote, place-based learning. Walking is not seen as time wasted, but rather as time gained for connective, engaging learning.

Through narrative and photography, I braid together stories, teaching moments and embodied research. I explore what can be unearthed-ecology, embodied knowledge, environmental ethicswhen we walk on the land. Hasebe-Ludt et al. (2009) explain that "métissage offers a rapprochement between alternative and mainstream curriculum discourses and seeks a genuine exchange ... to go out into the world, to embrace it and love it fiercely" (p. 9). With métissage as a frame and a guide, I examine how walking curricula can cultivate ecological learning and environmental connection. Métissage can be related to hybridity and heterogeneity (Roth, 2008); its lexical origin belongs to the Canadian word Métis, and from that the Latin word mixticius, meaning "mixed" or "multiple identities" (Hasebe-Ludt et al., 2009) but also means to use different fibres to weave a cloth (Merriam-Webster, n.d.). Both definitions serve this paper, in that I will weave different events, disciplines and timeframes-mostly from my own life, though inspired by others, including otherthan-humans - to create a chronicle in relation to walking pedagogy. As St. Georges (2020) elucidates, "Métissage is a method and a theory that mixes, contrasts, and juxtaposes multiple narratives in various literary forms of creative non-fiction" (pp. 13-14). Like her, I have stretched the métissage to include a visual element through photography. The photographs, meant to integrate and illuminate the text, are uncaptioned. ${ }^{1}$

${ }^{1}$ Also, note that all photographic images here are the work of the author and are used with permission. 


\section{Walking the Unexpected}

The moment I hoped for almost didn't happen.

After weeks of preparation, from signing liability forms, arranging carpools and ensuring all 35 students arrive at the same place at the same time, we are snowed out. Or, at least, the first trail is ankle-deep in snow, still lingering from last week. The undergraduate students are dressed for a casual walk, not a snowshoeing expedition. Nevertheless, I proceed.

Unlike my science students, where biomes, interspecific interactions, biotic nomenclature and other quantifiables are the prescribed outcomes, this is the first gaggle of expressive arts students I brought to Tynehead Park in Surrey, British Columbia. We began with storytelling a nature encounter, as I often do with my biology students, and I then segued into opening the senses (Young et al., 2010). Students embodied their owl eyes, deer ears, raccoon hands and dog nose.

Dog nose? I can hear the academics decry. Sounds childish. How is it relevant to the curriculum? Especially for adult learners?

While naturalized outdoor environments are often encouraged for young learners, since they improve sensory and kinaesthetic awareness (Wilson, 2012), post-secondary institutions prioritize the abstract, analytical and rational, a priory carried over from the Enlightenment, which had "no use for notions of life, sentience, experience, subjectivity, corporeal embodiment and agency" (Weber, 2013, p. 15). My teaching is often visceral, sensorial and embodied. What do students learn from this?

First, they learn that the mind is not the only realm where learning occurs. A conventional classroom has four walls, desks in rows, with an orator at the front. Fortunately, this has shifted in many schools, though less so in post-secondary, where lecture persists as the primary means of content delivery (Stains et al., 2018). A curriculum that singularly favours the mind also devalues, by its omission, bodily, emotional and spiritual ways of knowing. As Indigenous scholar and botanist Robin Wall Kimmerer (2012) explains, we want learners to "engage all of their human faculties of mind, body, emotion, and spirit which conventional science education practices tend to let atrophy" (pp. 320-321).

Second, learning with and through the body can be joyful, relational and deeply engaging. Whether I'm in an arts classroom, a science lab, or (preferably) in an outdoor learning environment, I regularly have students move their bodies through the space. They line themselves up as samples on an electrophoresis gel, build a circulatory system with chairs and tables and walk through it as blood cells, tread through the carbon cycle, or notice how the grass bends under their bare feet. Such activities nearly always prove exciting and eventful, and reveal unexpected learnings (Beavington, 2016) that a Powerpoint-based lecture doesn't afford. Even when they don't go as planned, something is gained. When you role-play a carbon atom, moving from the atmosphere to leafy producers, to hungry consumers, to putrid decomposers, and eventually back to the atmosphere, you have built a bodily memory, a physical journey perhaps more likely to be remembered, cared about and referenced in the future. I can ask learners, "Remember when you were decomposed in 
the carbon cycle?" Or, "What path did you take (literally) to return carbon dioxide to the atmospheric reservoir?"

Third, being engaged with our physicality: even a short 20-minute walk can release endorphins (Park et al., 2010), heighten awareness of our animality (Abram, 2011), and attune us to our full suite of senses. The separation between us and the outer world, largely perceived rather than actualized, since we are always embedded biologically in the environment, starts to dissolve. In other words, we feel more alive and entangled with other life. Is such learning-engaging, enlivening, envelopingnot a recipe for transformative pedagogy? In being present with our bodies' sensuous side, more in rhythm with muscle, blood and bone, we are reminded that humans are one type of body (of many) that comprise our biosphere. I believe this is as relevant for the preschooler as it is for the post-doc.

As Kimmerer (2012) writes about leading field experiences:

They come away knowing more plants, more processes, more chemistry, and more ecology than when they began and knowing it in a different way, through direct relationship of mind, body, emotion, and spirit—not because I have taught them, but because the land has. They walk humbly on the trails not as through a warehouse from which they take, but as through a home, from which they receive. This is the beginning of reciprocity. I do not think it is possible to engage in reciprocity without first experiencing the gifts of the land and then being drawn to return a gift in kind. (p. 321)

On this note, let's return to snowy Tynehead Park. The 35 students have stretched their senses. Having focused their eyes on a single spot, trained their ears to the nearest sound (often their own breathing) and the furthest (cars in the distance), noticed how their clothes and the breeze feel against their skin, smelled the cellulose (plucked grass) in their hands, and listened for the beating of their own hearts, they are ready for their next task. The invitation? To walk in silence, at a mindful pace, for the next few minutes, attuning our bodies to the coastal rainforest. Or as Kimmerer might say, to walk humbly.

Although I've walked this path dozens of times with students, never disappointed, the response today is exceptional. We gather on a wooden lookout platform. The voluminous bark of an old-growth grand fir - the biggest I've found in the park-and the rustling current of the river below asks us to stop here. A giant window has opened to reveal the temperate rainforest in its totality, which holds our collective silence. The natural environment has set the tone. How does it do this? This is difficult to pinpoint. Yet we can surmise a few possibilities. The grand fir's sheer size, with a trunk circumference that would take five students to ring around, its branches heavy with snow, and its top towering out of sight, is quite possibly the largest tree any of these students have ever seen. The lookout platform is also a natural place to stop, offering a view of this park's namesake, the Serpentine River. (I inform students at the start of the field trip that Tynehead refers to "Serpentine" and "headwaters", although the headwaters are actually located beneath the nearby Guildford Mall parking lot.) The river, its larger boulders iced with snow, wends through a small ravine, offering a view of hundreds of plant species that requires more than a quick glance to take in. Evergreen conifers, leafless maples, ferns and moss create a living, breathing mosaic. 
I am a guide here, and nature is the teacher (Jickling et al., 2018). In this case, the snow-which I had deemed an obstacle, or at least a deterrent-became the highlight experience.

I asked students what they noticed. They voiced their feelings and reflections with an excited reverence. By keeping silent, they could hear so much more. The crunch of the week-old snow felt loud as thunder. The icy path also meant that students took special care on how and where they placed their footsteps. They were intentional. The air felt cooler, fresher. They could see their breath. They were curious about the snowberry drupes and if they were edible. There were tracks from nonhuman animals. The students' awe for this place and the rarity of snow, cultivated through purposeful sensory experience, was palpable.

Humphreys (2018) speaks of her own childhood school experience, where she gleefully watched the snowfall outside the classroom windows. A gift, as Kimmerer might say, from the clouds. But the teacher stuck to her lesson plan. "When the bell rang we were let outside, but it had warmed up. The delicate dryness of the first snow had already disappeared" (Humphreys, 2018, p. 57). So, too, did a potential experience disappear, the result of a static curriculum, like following a routine script better served by improvisation. How much more engaging, curious, wonder-filled, connective, spontaneous, memorable and joyful would it have been for these learners to venture into the schoolyard for the first snowfall of the season? Later in life, at Maple Ridge Environmental School, Humphreys (2018) observed new snow as

not a distraction but an affordance, a learning opportunity. The assignment that emerged from the moment of the fallen snow was to collect snowflakes to be examined under a microscope. From here began lessons on temperature, on dimensions, on collecting, on difference, on patterns, on counting, and later the inspiration for snowflake art and sculpting. All of these lessons occurred while the children were outside walking. (pp. 57-58)

Walking amongst the snowflakes of a gentle flurry, the emergent learning opportunities are myriad (see Table 1). Teachers are often expected to fragment and articulate learning that happens in schools. In reality, much like the senses, these disciplines, topics and activities easily shift and blend with one another. We don't instruct students to use only the sense of touch for an entire class period; similarly, when learning in an emergent way outdoors, we don't need to limit learning to a single focus. 


\begin{tabular}{|c|c|c|}
\hline Discipline & Topics & Activities \\
\hline Geography & $\begin{array}{l}\text { Weather, } \\
\text { hydrology }\end{array}$ & $\begin{array}{l}\text { Track mountains, clouds and falling snow, then } \\
\text { speculate on where new snowmelt will go. }\end{array}$ \\
\hline Biology & $\begin{array}{l}\text { Hibernation, } \\
\text { adaptations }\end{array}$ & $\begin{array}{l}\text { Notice how birds tuck in their heads, what trees } \\
\text { they take cover in, and what other animal } \\
\text { species are present. }\end{array}$ \\
\hline Chemistry & $\begin{array}{l}\text { Physical properties } \\
\text { (density, melting point) }\end{array}$ & $\begin{array}{l}\text { Observe solid ice forming over liquid water, or } \\
\text { how snow melts in our hand. }\end{array}$ \\
\hline $\begin{array}{l}\text { Indigenous } \\
\text { Knowledge }\end{array}$ & Ethnoscience, igloos & $\begin{array}{l}\text { Have the class construct and put together } \\
\text { blocks of hard snow. }\end{array}$ \\
\hline Agriculture & $\begin{array}{l}\text { Snowmelt availability, } \\
\text { thermal insulation }\end{array}$ & $\begin{array}{l}\text { Consider increased river flow, and how all the } \\
\text { plants beneath the newly forming blanket of } \\
\text { snow survive. }\end{array}$ \\
\hline Physical Education & Winter sports, recreation & Build and use sledding tracks. \\
\hline Nature Connection & Animal tracking & $\begin{array}{l}\text { Follow and interpret bird and mammal prints in } \\
\text { the snow. }\end{array}$ \\
\hline
\end{tabular}

Table 1. Disciplines, topics and activities that can be taught and explored in the snow, specific for elementary learners, though relevant across all age groups.

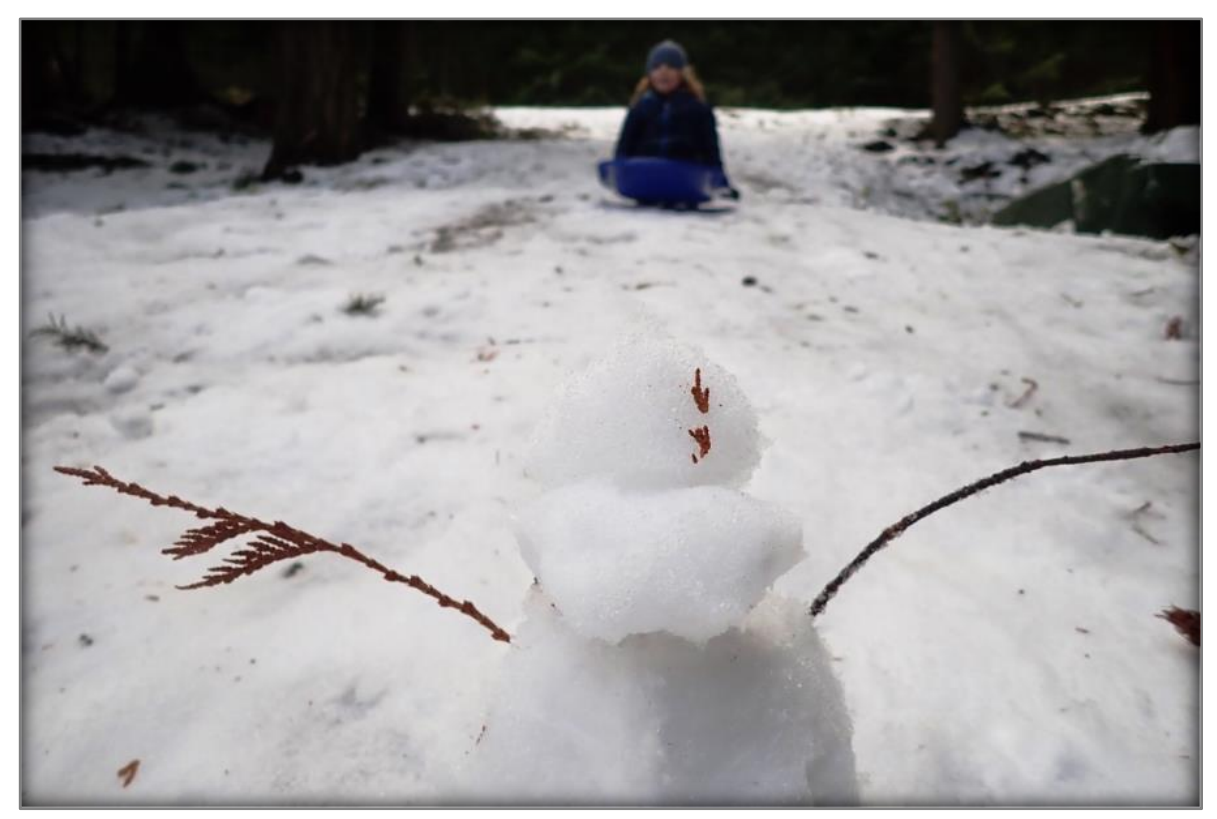


Or students could have simply enjoyed the miracle of first snow through bodily experience and built snowmen and slid down hills. There is a difference between taking an activity outside and learning with or through nature; the latter necessitates more intentionality on the part of the teacher, and it encourages the voice of nature to be heard. Plunking a desk in a field, and having students listen to a lecture is a distinct experience from active outdoor engagement where nature has agency and co-facilitates student learning through direct sensorial attunement. This can lead to notions of reciprocity, where students are not learning about nature, but are companions with the natural world.

Of course, many of the topics in Table 1 can be blended and co-studied. I break them down here for the purpose of showing the diversity of learning that can occur in company with a single weather type. After returning to class, other subjects, for older learners, take on significant relevance (see Table 2).

\begin{tabular}{|c|c|c|}
\hline Discipline & Topics & Activities \\
\hline $\begin{array}{l}\text { Environmental } \\
\text { Science }\end{array}$ & Climate change & Does falling snow contravene global warming? \\
\hline Fine Arts & $\begin{array}{l}\text { Creative writing, } \\
\text { drawing, painting }\end{array}$ & $\begin{array}{l}\text { Writing prose or poetry, or drawing or painting, } \\
\text { either about, or inspired by, their experience. }\end{array}$ \\
\hline Geography & Local weather history & Changes in snowfall patterns over time. \\
\hline $\begin{array}{l}\text { Indigenous } \\
\text { Knowledge }^{2}\end{array}$ & $\begin{array}{l}\text { Hunting, food storage, } \\
\text { transportation }\end{array}$ & $\begin{array}{l}\text { Research how some Indigenous peoples thrive } \\
\text { in arctic environments. }\end{array}$ \\
\hline Physics & $\begin{array}{l}\text { Ice crystals, cloud } \\
\text { physics }\end{array}$ & Research how clouds form ice crystals. \\
\hline
\end{tabular}

Table 2. Subjects, inspired by walking through snow, where follow-up learning can occur in the classroom,
for learners in high school and post-secondary.

When delivering professional development workshops for $\mathrm{K}-12$ teachers, I have noticed a reluctance to go outside. The number of variables to keep track of -temperature, terrain, safety, precipitation, snow — can be daunting. As Fleischner et al. (2017) explain, "Field courses also require extraordinary effort that is typically undertaken without adequate institutional support for out-ofclass faculty time invested in planning, pre-trip reconnaissance, logistic preparation, and fulfillment of the regulatory demands of training, liability, and permitting" (p. 561). Yet the potential rewards are limitless. This emergent learning requires flexibility and adaptability (Beavington, 2018). Like an amoeba, it shapeshifts based on what it encounters to allow learning to be guided not only from the learners, but also from the environment. When it snows, the script should change; better yet, scrap the script, and let the students tell the story.

${ }^{2}$ Indigenous ways of knowing can encompass and manifest in many other subjects. 


\section{Concerning Hobbits and David Abram}

My three-year-old daughter throws off her shoes and declares: "I'm walking bare feet!" We venture into fern alley, soles crunching dried salal leaves and toes curling around fir cones. I watch her senses engage with the forest. The collective rustle of high alder leaves signals imminent weather. The viscosity of mud squishing between her toes, the shifting path the small creek takes when she dams it with dirt, the sweet pungency of stinging nettle-all provoke deeper awareness.

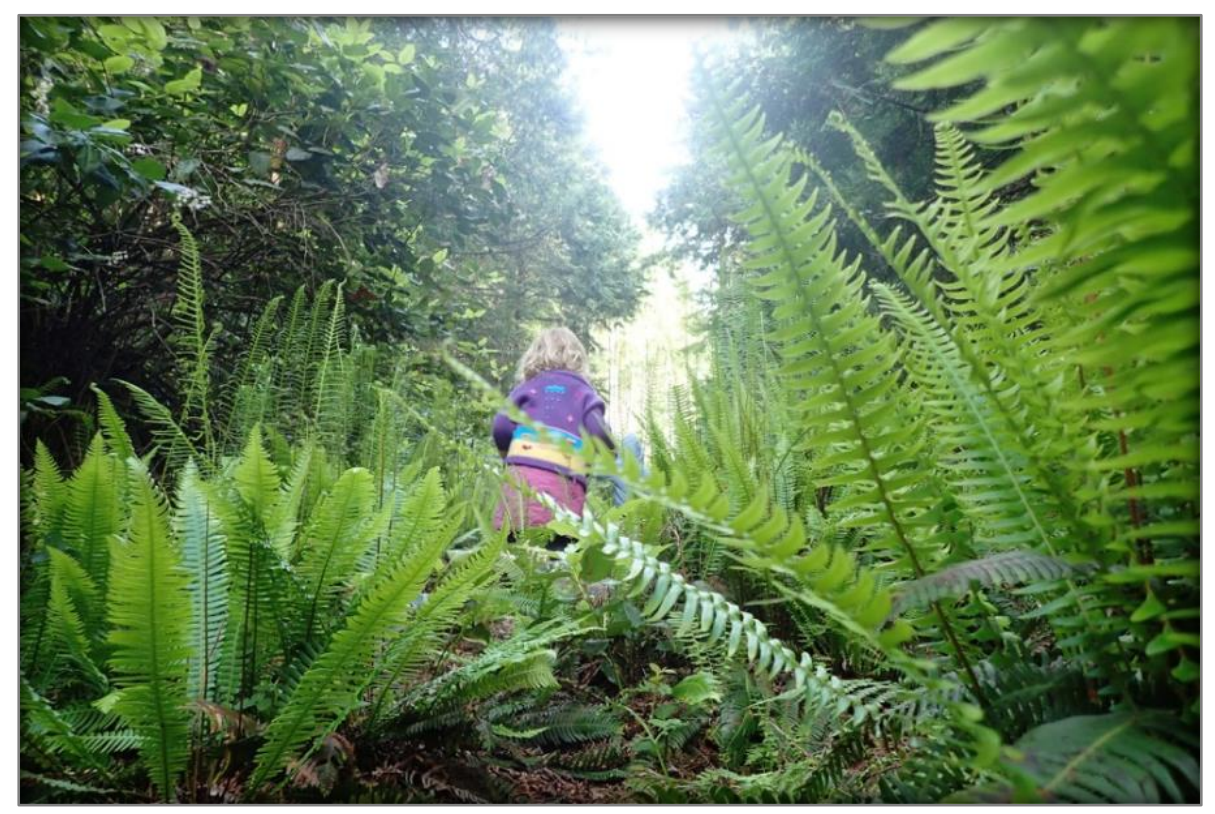

Of course, my daughter doesn't use these words. Yet her body is forging muscle memories, synapsing experiences into grey matter, and embodying what the temperate rainforest has to offer. With every step, she builds a new relationship with the soft cushion of moss, the unstable scree down to the creek and the bank's sinking muck. Occasionally, she roots her feet to the earth, noticing how her body is part of this larger body. My daughter and I come to this place often. Every visit offers a new discovery (another tributary of the creek), change (fiddleheads unfurling), or disturbance (human garbage). 


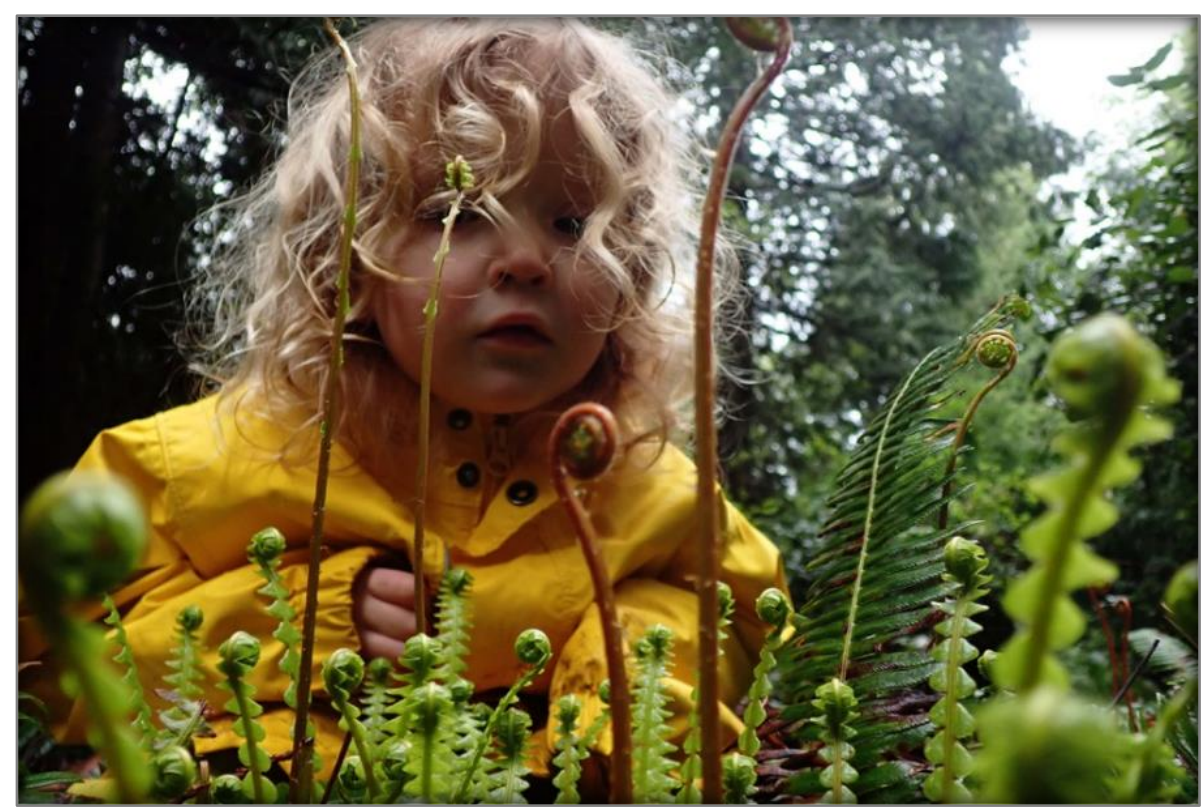

How can this embodiment (Richmond \& Snowber, 2011; Snowber, 2016) translate into teaching and learning? Direct sensorial experience offers not only active and experiential pedagogy, but also a spiritual attunement with the natural world. Now, amid the climate crisis and screen pandemic, such Earth resonance is of utmost import. For many people, walking through a temperate rainforest, or alongside a stream, elicits a sense of the interrelation of all beings (what ecology science quantifies), as well as a sense of the sacred.

Outdoor learning environments are less static than classrooms. This increases both the unpredictability and the spontaneity. My daughter's determination to go barefoot, and the fact that hobbits walked to Mordor barefoot, reminds me that I can, at the very least, walk barefoot in my backyard.

David Abram once led me through a walking exercise. In 2017, he offered a graduate class at the University of British Columbia, Between the Body and the Breathing Earth (notably, on my official academic transcript, the much more pedantic course title reads: Special Course in Curriculum and Pedagogy). Next to Nitobe Memorial Garden, we tried to find a quiet, treed spot on the campus, which turned out to be impossible. Trees, yes. Quiet, no. Construction, heck yes.

Abram (1996) is an ecophilosopher. A proponent of oral storytelling, of embodying who we are, especially in relation to the land, he is also a self-proclaimed madman. During this course in phenomenology, the study of first-person experience, he invited us to think with our skin. Since the senses co-create the world, and "perception is the glue that connects our nervous system to the surrounding ecology" (personal communication, July 10, 2017), we should see the body as a thinking being.

The instructions are simple. Take off your shoes and walk the paved path. 
The pavement feels flat, hard, unyielding. Each step, my ball and heel push against the smooth asphalt. The rest of my foot makes no contact. Something doesn't feel right about my sole touching this surface. Shoes required.

David's next instruction: walk the bare earth.

This also feels solid, but in a different way. My foot, held by the grass and dirt, moulds itself to the surface. At the same time, the surface moulds itself to my foot. A rootedness accompanies each step. My toes hug twigs and cones, testing, sensing and reacting to their textual bodies. My skin feels the prick of unexpected thorns.

This feels like a simple exercise. Perhaps, much like walking a forest path in silence, the simplicity is what allows for something profound. The primacy of experience allows for holding our attention to touching the earth and to the earth touching us. While the pavement does not respond to my steps, the earth reciprocates like well-fitted orthotics, with texture, flex and counsel. Without sock or shoe to interfere, my sole can now discern soil and rock, sharp and smooth, wet and dry, warm and cool. If graduate students can do this, why not learners of any age?

Without shoes, you are more bodily aware, more mindful of each step, led more by your senses and less by habit. If the body is a thinking being, then every pore, hair, and sensory neuronsuch as the 200,000 nerve endings on the sole of each foot-can be made available for clarity of thought. To think with our feet is to think with the earth.

\section{Walking Away from Screens and Convention}

A seed is directly shaped by the available soil, sunlight and rainfall. Similarly, our familial and collegial relationships influence our character, whereas our relationship with nature determines the purview of our environmental ethic. If we walk solely on pavement, never sit still long enough to listen to the other-than-humans, and primarily experience the natural world through screens, our relation to nature may also be rendered artificial. Such limited and simulated encounters with the natural world do not imprint themselves as powerfully as an immersive trek through the animacy of the temperate or tropical rainforest, both of which I have observed indelibly leave their mark.

With the intensification of the "screen pandemic" (Helander et al., 2020; Jiang, 2020), and increased eye strain and numerous physical issues related to screen time, the regular curriculum needs to be re-assessed. What and how we taught pre-COVID-19 cannot simply be transferred to a screen-based device. Despite this screen fatigue, nearly everything at my university is now online: registration, meetings, office hours, lectures and exams. Yet one might argue that our students need less screen time, not more (Louv, 2005). For example, Kuo and Taylor (2009) found that children diagnosed with $A D H D$, after being led on a park walk for 20 minutes, displayed improved concentration comparable to the effects of using common ADHD medication. Given the coronavirus pandemic, how can screens be used to facilitate outdoor experiences?

Thoreau wrote, "I think I cannot preserve my health and spirits, unless I spend four hours a day at least ... sauntering" (Emerson \& Thoreau, 1992, p. 74). Compare this to today's Canadian children, 
who average 8.2 sedentary hours a day (Humphreys, 2018), versus 20 minutes of outdoor play (Juster et al., 2004). We are in dire straits.

In preparation for the summer 2020 semester, my colleagues at KPU and I scrambled to design and implement remote teaching alternatives to typically in-person, experiential learning. The specific challenge I will speak to here is BIOL 2322 (Ecology), a second-year science course, whose lab component is field-trip based. How to replicate through a screen the experience of being in the forest, bog or river?

Thus, was born the Ecology in $1 \mathrm{~m}^{2}$ study. In collaboration with Amy Huestis and Carson Keever, we created an inquiry-based activity (or rather, experience) where students periodically visited the same one-square meter plot in their environment, continuously noting species interactions that they observed in their plots. Students learned how to accurately depict their environment, and science students were paired with fine arts students to cross-pollinate questions and ideas.

I noticed several elements in this activity in relation to walking. First, regardless whether a student's site was in their backyard, the park down the road, or the university campus, students needed to walk there. They had to get out of their house and embody this experience. Senses other than sight and sound were engaged. They smelled the freshly cut grass, turned over stems and leaves to search for invertebrates. The natural sciences are typically head-centric, neglecting the difficult-to-quantify scent and taste. Yet when "we insist on only what can be characterized quantitatively, we thereby forgo a lot of information" (Landman-Reiner, 2020, p. 2). Students indicated how peaceful and relaxing they found this exercise and noted how the world around them (usually environments they saw every day) opened up. They started to ask questions, curious about why they saw ants on the cherry tree, which species were invasive, and why the birds were calling. I believe the corporeal aspect of this experience, and having to move (i.e., walk) to their sites, helped facilitate this connection and curiosity. This was not only an intellectual journey, but a physical one as well.

Does how we walk matter? Most certainly. When we learn to walk with care and intention, we are "changing—softening-[our] presence in the world" (Young \& Gardoqui, 2013, pp. 61-62). I have been extraordinarily privileged and blessed to travel to the remote Colombian Amazon Rainforest as an instructor for the Amazon Interdisciplinary Field School at KPU. Our guide, Elvis, invited us to wake early one morning for an optional wildlife walking expedition. One student and I showed up, wearing the standard gumboots required for the muddy paths. Partway through the walk, Elvis told the student that he needed to show her how to walk. Rather than clomping her foot down, she needed to plant each step with care, placing the ball of her foot first, and then rolling back onto her heel. In this way, she made less noise, and brought an intentionality to her gait.

Goertz (2018) elucidates how walking promotes divergent (rather than convergent) thinking, and "is an excellent facilitator of original, innovative thinking because the physical act of left-right steps simulates the integration of the two halves of the brain, the logical and the intuitive" (p. 61). Walking meetings are a great way to discuss walking curriculum (what we teach, content that we 
emphasize) and pedagogy (teaching philosophy, how we teach). Perhaps walking can also allow us to "embrace and enact a pedagogy of place within landscapes of the natural surroundings, family and community, and the affective foundations of a life lived in a respectful reciprocal relationship with the world" (Kelly, 2012, p. 364).

I still fall into the trap of equating walking to time wasted. My co-presenter, Dave Chang, and I prepped for a presentation at the University of British Columbia, on the topic of Aldo Leopold and the GPS ecocache (Beavington \& Jewell, 2018). Leopold was a conservationist and proponent of learning on the land, while the GPS ecocache is an activity where students navigate to specific ecological sites and learn something at each location. Dave and I shot ideas back and forth for our presentation. We wanted to take participants outside and make our way to a coveted site (the same chosen by David Abram) next to the Nitobe Memorial Garden near the outskirts of campus. I lamented: "We'll lose so much time by walking there. If only we had a teleporter!" In pondering places to visit along the way-the ponderosa pine outside Carl Leggo's office, the nurse stump along Lower Mall Road-it struck me. Rather than diversions, these could very well be the highlights. The anchors of our interactive talk. My mind eventually shifted to the idea that the walk itself could be the presentation.

The same goes for teaching. A path, field, yard or road can all be mobile classrooms. Walking as pedagogy is not a new phenomenon. Thoreau opened a school that included regular nature walks as part of the curriculum. Yet, in our modern insular lives, we need to get past our own preconceptions of where and how learning happens.
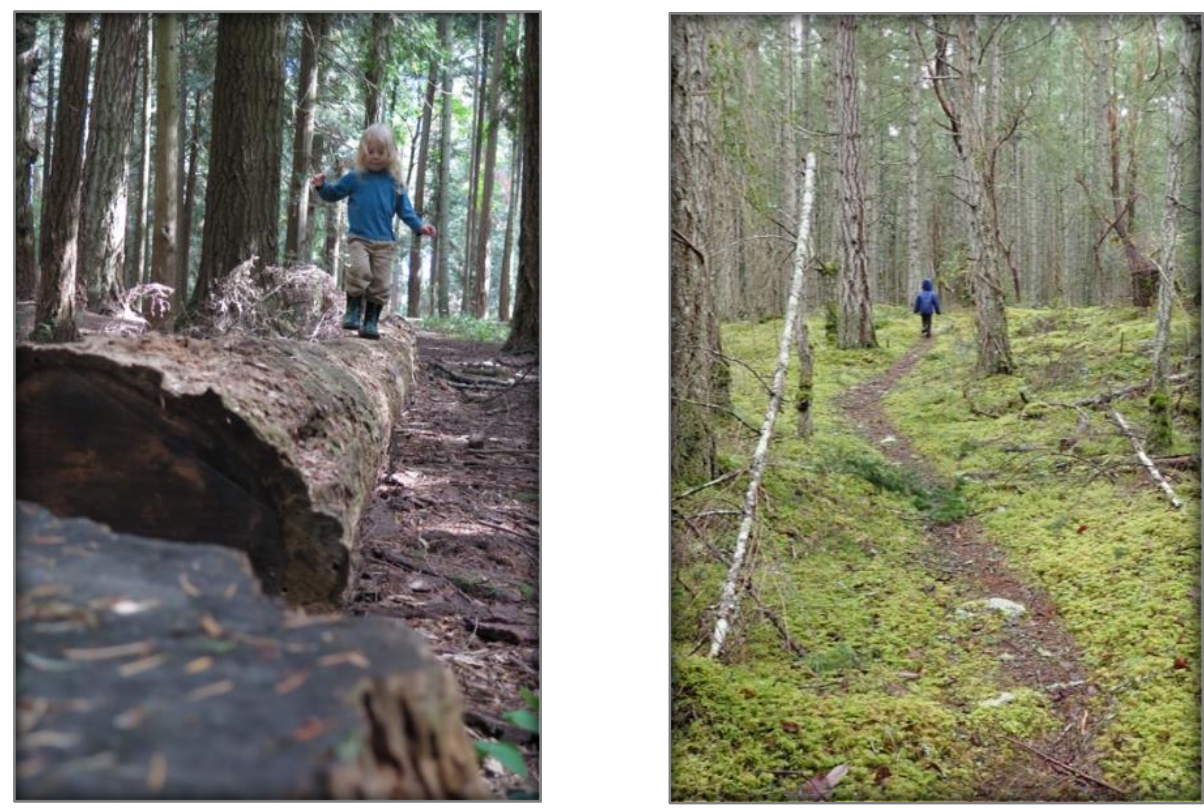
I recently taught an introductory biology course. The course outline prescribed three midterms and 10 quizzes. I had taken students on a field trip (a first for this long-offered course) earlier in the semester. It had gone so well, I wanted to do a second. But students had a quiz to write, and a midterm to review. I still vividly remember the epiphany of getting past my conventional thinking: they can do these outside. We went to a local park, where the cherry blossoms were in full bloom, rather fitting for the day's topic: the nervous (or sensory) system. We began with the requisite quiz, outdoors, perhaps a first for all of us, and certainly incongruent with the remainder of this experience. Then the students connected what they were directly experiencing-hearing a crow caw, smelling a nascent bloom, watching the clouds roil overhead-with what they had learned about their own brain and nervous systems. Nothing else from this semester came close to being as engaging, curious, wonder-filled, connective, spontaneous, memorable and joyful.

And it almost didn't happen.

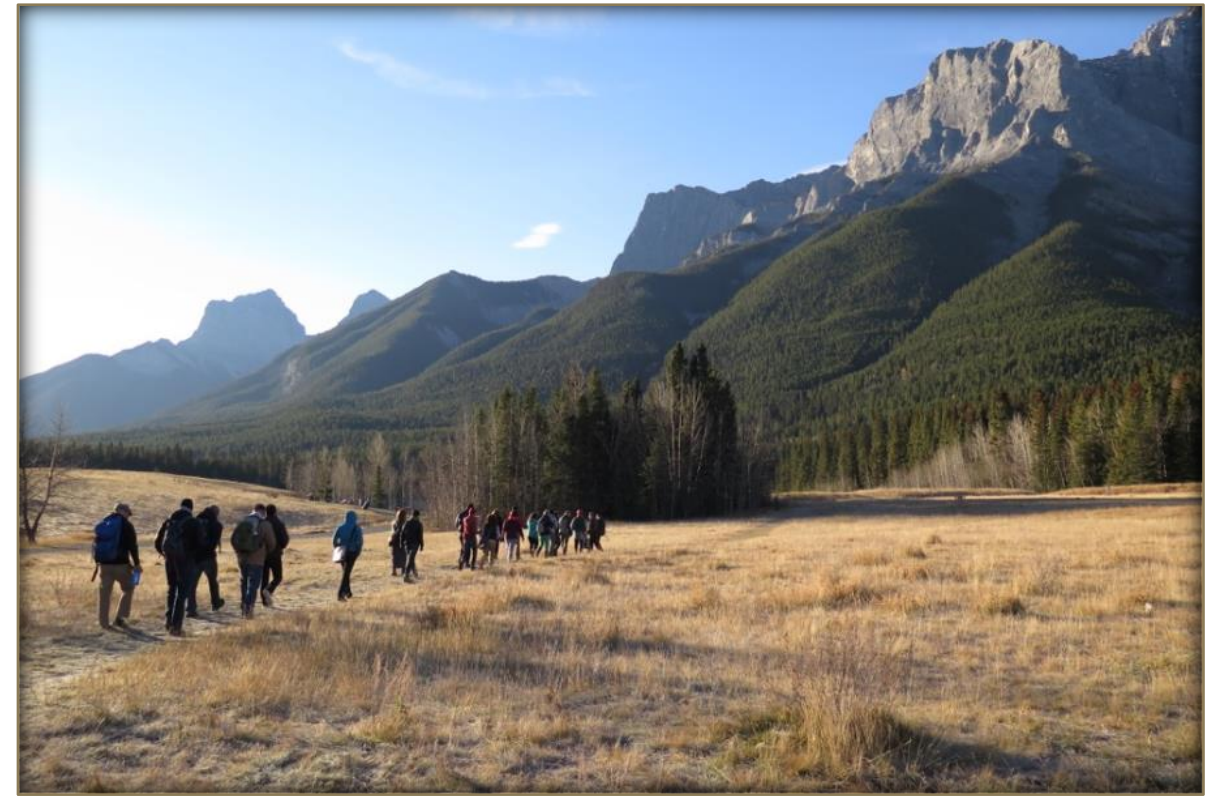

\section{About the Author}

Lee Beavington is a river walker, forest seeker and island dweller. He is a TEDx speaker, awardwinning author, learning strategist and interdisciplinary instructor at Kwantlen Polytechnic University and Simon Fraser University. He also served as co-curator for the Wild Things: The Power of Nature in Our Lives exhibition at the Museum of Vancouver, recipient of the Award of Merit for Excellence in Exhibitions. His interdisciplinary research explores environmental ethics, place-based learning and contemplative science education. More about Lee at www.leebeavington.com.

\section{Acknowledgements}

This work was supported by Mitacs through the Mitacs Research Training Award. 


\section{References}

Abram, D. (1996). Spell of the sensuous: Perception and language in a more-than-human world. Vintage.

Abram, D. (2011). Becoming animal: An earthly cosmology. Vintage.

Beavington, L. (2016). A creative approach: Teaching biology labs through arts-based learning. In K. McMahon (Ed.), Tested studies for laboratory teaching. Association for Biology Laboratory Education. http://www.ableweb.org/volumes/vol-37/?art=26

Beavington, L. (2018). The jaguar walk: Reflections from the Amazon Field School. Transformative Dialogues, 11(3), 1-10. https://journals.kpu.ca/index.php/td/article/view/141

Beavington, L., \& Jewell, J. (2018). GPS ecocache: Connecting learners to experience and place, American Association of Philosophy Teachers Studies in Pedagogy, 4, 161-180. https://doi.org/10.5840/aaptstudies201922539

Chambers, C., Hasebe-Ludt, E., Leggo, C., \& Sinner, A. (Eds.) (2012). A heart of wisdom: Life writing as empathetic inquiry. Peter Lang.

Emerson, R. W., \& Thoreau, H. D. (1992). Nature and walking. Beacon Press.

Fleischner, T., Espinoza, R., Gerrish, G., Greene, H., Kimmerer, R., Lacey, E., Pace, S., Parrish, J., Swain, H., Trombulak, S., Weisberg, S., Winkler, D., \& Zander, L. (2017). Teaching biology in the field: Importance, challenges, and solutions. BioScience, 67(6), 558-567. https://doi.org/10.1093/ biosci/bix036

Goertz, K. (2018). Walking as pedagogy. In C. Hall, Y. Ram, \& N. Shoval (Eds.), The Routledge international handbook of walking (pp. 55-64). Taylor \& Francis. https://doi.org/10.4324/ 9781315638461

Hasebe-Ludt, E., Chambers, C. M., \& Leggo, C. (2009). Life writing and literary métissage as an ethos for our times. Peter Lang.

Hasebe-Ludt, E., \& Leggo, C. (Eds.) (2018). Canadian curriculum studies: A métissage of inspiration/imagination/interconnection. Canadian Scholars.

Helander, M., Cushman, S., \& Monnat, S. (2020, May 26). A public health side effect of the coronavirus pandemic: Screen time-related eye strain and eye fatigue. Lerner Center for Public Health Promotion. https://lernercenter.syr.edu/2020/05/26/ib-24

Humphreys, C. (2018). Dynamic horizons: A research and conceptual summary of outdoor education. The Council of Outdoor Educators of Ontario. https://www.coeo.org/wp-content/uploads /2019/07/COEO2018DynamicHorizonsPDF.pdf

Jiang, M. (2020, April 22). The reason Zoom calls drain your energy. BBC. https://www.bbc.com/ worklife/article/20200421-why-zoom-video-chats-are-so-exhausting

Jickling, B., Blenkinsop, S. Timmerman, N., \& De Danan Sitka-Sage, M. (Eds.). (2018). Wild pedagogies: Touchstones for re-negotiating education and the environment in the Anthropocene. Palgrave Macmillan. 
Juster, F. T., Stafford, F., \& Ono, H. (2004). Changing times of American youth: 1981-2003. Institute for Social Research, University of Michigan. http://www.ns.umich.edu/Releases/2004/ Nov04/teen_time_report.pdf

Kelly, V. (2012). A Métis manifesto. In C. Chambers, E. Hasebe-Ludt, C. Leggo, and A. Sinner (Eds.), $A$ heart of wisdom: Life writing as empathetic inquiry (pp. 363-368). Peter Lang.

Kimmerer, R. W. (2012). Searching for synergy: Integrating traditional and scientific ecological knowledge in environmental science education. Journal of Environmental Studies and Sciences, 2(4), 317-323. https://doi.org/10.1007/s13412-012-0091-y

Kuo, F., \& Taylor, F. (2004). A potential natural treatment for attention deficit/hyperactivity disorder: Evidence from a national study. American Journal of Public Health, 94(9), 1580-1586. https://dx.doi.org/10.2105\%2Fajph.94.9.1580

Landman-Reiner, A. (2020). Complementing reductionism: Goethean science part 1: Qualities and wholeness. EXPLORE: The Journal of Science \& Healing, 00(2020), 1-6. https://doi.org/10.1016/j.explore.2020.02.015

Louv, R. (2005). Last child in the woods: Saving our children from nature-deficit disorder. Algonquin. Merriam-Webster. (n.d.). Métis. In Merriam-Webster's collegiate dictionary (11th ed.). Retrieved September 1, 2021, from https://www.merriam-webster.com/dictionary/metis

Park, B. J., Tsunetsugu, Y., Kasetani, T., Kagawa, T., \& Miyazaki, Y. (2010). The physiological effects of Shinrin-yoku (taking in the forest atmosphere or forest bathing): Evidence from field experiments in 24 forests across Japan. Environmental Health and Preventive Medicine, 15(1), 18-26. https://doi.org/10.1007/s12199-009-0086-9

Richmond, S., \& Snowber, C. (2011). Landscapes of aesthetic education. Cambridge Scholars.

Roth, W. M. (2008). Bricolage, métissage, hybridity, heterogeneity, diaspora: Concepts for thinking science education in the 21st century. Cultural Studies of Science Education, 3(4), 891-916. https://doi.org/10.1007/s11422-008-9113-1

Snowber, C. (2018). Embodied inquiry: Writing, living and being through the body. Springer.

St. Georges, D. (2020). Embodied landscapes: A creation-research Indigenous métissage. [Doctoral dissertation, Concordia University]. Spectrum Research Repository. https://spectrum.library. concordia.ca/986826/

Stains, M., Harshman, J., Barker, M., Chasteen, S., Cole, R., DeChenne-Peters, S., Eagan, M. K., Esson, J., Knight, J., Laski, F., Levis-Fitzgerald, M., Lee, C., Lo, S., McDonnell, L., McKay, T., Michelotti, N., Palmer, M., Plank, K., Rodela, T., .. Young, A. (2018). Anatomy of STEM teaching in American universities: A snapshot from a large-scale observation study. Science, 359(6383), 1468-1470. https://doi.org/10.1126/science.aap8892

Weber, A. (2013). Enlivenment: Towards a fundamental shift in the concepts of nature, culture and politics. Heinrich Böll Foundation. https://www.boell.de/sites/default/files/enlivenment_v01.pdf

Young, J., Haas, E., \& McGown, E. (2010). Coyote's guide to connecting with nature ( $2^{\text {nd }}$ ed.). OWLLink Media.

Young, J., \& Gardoqui, D. (2013). What the robin knows: How birds reveal the secrets of the natural world. Houghton Mifflin Harcourt. 